\title{
Upaya Komunitas Bringin Muda Bersemi (BMB) Dalam Meningkatkan Literasi Melalui Ahad Literasi Di Desa Bringin Kauman Ponorogo
}

\author{
Anggraini Nurpitasari \\ Mahasiswa FATIK IAIN Ponorogo, Indonesia \\ Email: anggranurpitasari@gmail.com \\ Muhammad Heriyudanta \\ IAIN Ponorogo, Indonesia \\ Email: yudanta1o@gmail.com \\ Marjanji \\ SDN Bogorejo Rembang, Indonesia \\ Email: Marjanji11@gmail.com \\ Galuh Sitaresmi \\ Magister Geografi UGM Yogyakarta, Indonesia \\ Email: galuh.sita88@gmail.com
}

DOI: https://doi.org/10.21154/sajiem.v2i2.76

\begin{abstract}
Penelitian ini dilatar belakangi oleh rendahnya minat baca anak di desa Bringin Kauman Ponorogo. Hal ini disebabkan karena kurangnya kesadaran orang tua akan pentingnya membaca, kebiasaan anak yang lebih memprioritaskan untuk bermain gadget dari pada membaca buku ditambah dengan sekolah yang meliburkan siswa untuk tidak melaksanakan kegiatan pembelajaran di kelas tetapi meminta untuk belajar di rumah selama pandemi Covid-19. Penelitian ini bertujuan untuk mendeskripsikan eksistensi komunitas Bringin Muda Bersemi (BMB) dalam kegiatan literasi, upaya yang dilakukan dalam meningkatkan literasi, faktor pendukung dan penghambat
\end{abstract}


serta implikasi program ahad literasi bagi anak-anak. Untuk menjawab penelitian diatas peneliti menggunakan pendekatan kualitatif dengan jenis penelitian data deskriptif kualitatif. Teknik pengumpulan data yang meliputi observasi, wawancara, dan dokumentasi. Adapun teknik analisis data mengunakan redukasi data, penyajian data, dan pengambilan verifikasi. Berdasarkan hasil penelitian menunjukan kesimpulan adalah eksistensi komunitas Bringin Muda Bersemi (BMB) dalam kegiatan literasi yaitu memberikan fasilitas dengan menyediakan berbagai buku dan tempat yang nyaman untuk kegiatan literasi bagi anak-anak yang berkunjung ke lapak buku. Upaya yang dilakukan oleh Bringin Muda Bersemi (BMB) dalam meningkatkan literasi dengan berbagai program kegiatan sebagai berikut: mengadakan kegiatan yang tidak berhubungan dengan buku, mengadakan penambahan koleksi buku, melakukan pendampingan bimbingan belajar, mengadakan bimbingan belajar. Faktor pendukung berasal dari lingkungan keluarga dan lingkungan luar. Implikasi program ahad literasi bagi anak-anak di desa bringin memberikan dampak positif. Dibuktikan antusias anak mengikuti kegiatan literasi sebelum kegiatan dimulai, mendapatkan pengalaman baru yang sebelumnya belum didapatkan di luar lingkungan sekolah, kebiasaan anak yang awalnya datang untuk bermain tetapi sekarang digunakan untuk membaca walaupun tidak semua anak.

Kata Kunci: Komunitas Literasi

\section{Pendahuluan}

Melalui membaca seseorang akan memperoleh infomasi yang baru yang sebelumnya belum pernah diketahuinya. Menurut Rahim membaca pada hakikatnya merupakan suatu yang rumit yang melibatkan banyak hal, tidak sekedar melafalkan tulisan tetapi juga melibatkan aktivitas visual dan berfikir. Banyak orang yang membaca kata demi kata, bahkan mengucapaknnya secara cermat, dengan maksud untuk memahami isi bacaan. Apabila semakin banyak membaca, maka semakin banyak pula informasi yang diperoleh. Oleh karena itu, membaca merupakan sebuah kompas menuju pengetahuan baru. ${ }^{1}$

Membaca adalah perintah Allah Swt yang diturunkan kepada Nabi Muhammad Saw untuk diajarkan kepada para umatnya melalui wahyu Allah

1 Chairunnissa, "Pengaruh Literasi Membaca Dengan Pemahaman", Jurnal Tuturan, 1 (Januari 2017), 749. 
Swt yang terkandung dalam Al-Qur'an yakni surat Al-Alaq ayat 1-5 sebagai berikut: ${ }^{2}$

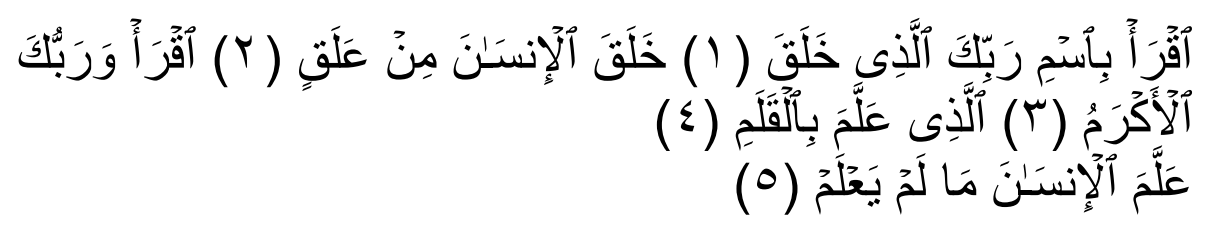

Artinya: "Bacalah dengan menyebut nama Tuhanmu yang Menciptakan, Dia telah menciptakan manusia dari segumpal darah, Bacalah dan Tuhan-Mu lah yang Maha pemurah yang mengajar (manusia) dengan perantara kalam, Dia mengajar kepada manusia apa yang tidak diketahuinya". ${ }^{3}$ (QS. Al-Alaq: 1-5).

Perintah membaca seperti yang telah dijelaskan dalam surat Al-Alaq pastinya tidak hanya ditunjukan kepada Nabi Muhammad Saw, tetapi perintah membaca tersebut bersifat umum yang ditunjukan kepada seluruh umat manusia. Membaca sebagai suatu ajaran yang dapat memberikan manfaat dan keutamaan bagi seseorang di dalam kehidupannya. Sebagaimana yang dijelaskan dalam surat Al-Alaq bahwasanya dengan membaca seseorang akan mendapatkan pengetahuan yang sebelumnya tidak diketahui. Dengan kegiatan membaca seseorang akan bertambah keilmuan dan pengetahuannya. ${ }^{4}$

Indonesia tercatat sebagai salah satu negara yang berhasil mengurangi angka buta huruf. Data UNDP tahun 2014 mencatat bahwa tingkat kemelekhurufan masyarakat Indonesia mencapai 92,8\% untuk kelompok dewasa dan 98,8\% untuk kategori remaja. Pencapaian ini sebenarnya menunjukan bahwa Indonesia telah melewati tahapan krisis literasi dalam pengertian kemelekhurufan. Meskipun demikian, tantangan saat ini adalah rendahnya minat baca. Selain kesedian buku di seluruh Indonesia belum memadai, pemerintah juga menghadapi rendahnya motivasi membaca di kalangan peserta didik dituntut untuk memiliki kemampuan membaca dalam pengertian teks secara analitis, kritis, dan reflektif. ${ }^{5}$

${ }^{2}$ Departemen Agama RI, Al Qur'an Tajwid E Terjemah (Bandung: CV Penerbit Diponegoro, 2014), 169.

3 Yayasan Penyelenggara Penerjemah Al-Qur'an, Mushaf Al-Qur'an Terjemah (Jakarta: Al-Huda Kelompok Gema Insani), Juz: 30, Surat: Al-Alaq, Ayat: 1-5, 598.

${ }^{4}$ Farida Rahim, Pengajaran Membaca di Sekolah Dasar (Jakarta: Bumi Aksara, 2008), 1.

${ }^{5}$ Pangesti Wiedarti, Desain Induk Gerakan Literasi Sekolah (Jakarta: Direktorat Jenderal Pendidikan Dasar Dan Menengah Kementerian Pendidikan dan Kebudayaan, 2016), 1. 
Fakta tersebut dibuktikan hasil penelitian yang dilakukan oleh Programme for International Student Assesment (PISA) tahun 2012 bahwa Indonesia menduduki peringkat 60 dengan skor 396 dari total 65 peserta negara untuk kategori senang membaca. Padahal, skor rata-rata yang ditetapkan PISA sebesar 500. Pencapaian kemampuan terbaik literasi membaca tertinggi pada tahun 2012 ditempati oleh wilayah Asia Tenggara diraih oleh Singapura dengan perolehan skor $542 .^{6}$

Sebagaimana hasil pengamatan yang dilakukan oleh peneliti terhadap kondisi baca anak di desa Bringin menunjukan sangat rendah. Hal ini disebabkan oleh kurangnya kepedulian orangtua terhadap budaya membaca anak. Kebanyakan orangtua yang telah menyerahkan tanggungjawab pendidikan anak kepada sekolahan sehingga orangtua tidak lagi repot untuk mendidik anaknya salah satunya kegiatan membaca dan menulis. Ditambah dengan kondisi pendidikan yang ada di Indonesia saat ini mengalami penurunan. Covid-19 yang datang ke Indonesia telah membawa dampak yang cukup besar terhadap negara Indonesia salah satunya bidang pendidikan. Adanya perubahan sistem pendidikan yang biasanya dilaksanakan di lingkungan sekolah akibat pandemi Covid-19 yang mengharuskan kegiatan pembelajaran dilakukan dirumah.

Sehingga pihak sekolah harus menerapkan pembelajaran daring atau online dan meminta anak-anak untuk melakukan pembelajaran di rumah tetapi kebanyakan anak-anak mengunakan waktu yang seharusnya dimanfaatkan untuk belajar tetapi anak-anak memilih untuk bermain gadget, bermain dengan teman-temannya. Hal tersebut terjadi karena setiap hari mereka telah dibebankan tugas banyak tanpa ada penjelasan dari guru mata pelajaran tersebut. Pihak dari orangtua juga mengalami kesulitan untuk mengajarinya. Sehingga untuk menghindari hal tersebut anak memilih untuk bermain. Melihat masalah-masalah diatas mengenai pendidikan anak yang harus terus ditingkatkan, dari komunitas Bringin Muda Bersemi mengadakan kegiatan literasi.

Awal mula diadakan kegiatan literasi pada bulan Mei 2020 yang bertepatan dengan kegiatan KPM-DR yang diselengarakan oleh kampus IAIN Ponorogo. Kegiatan literasi tersebut bukan hanya menjadi program komunitas Bringin Muda Bersemi (BMB), tetapi menjadi salah satu program kerja anak KPM-DR sebagai rutinan setiap hari ahad. Anggota yang ikut bergabung dalam kegiatan literasi awalnya berjumlah hanya 6 orang yang terdiri dari 3 anggota Bringin Muda Bersemi (BMB) dan 3 mahasiswa KPM-DR bertambah 5 orang lagi, sehingga diperoleh 11 orang aktif dalam kegiatan. Pertama kali kegiatan lapak buku berlokasi di pelataran SD Darmawanita dan

${ }^{6}$ Ibadullah, Dewi Tryanasari, Apri Kartikasari, Pembelajaran Literasi Berbasis Sastra Lokal (Magetan: CV AE Media Grafika, 2017), 15-20. 
tempat kegiatan selanjutnya dialihkan ke balai desa Bringin. Menurut pendiri tempatnya startegis dan mendukung. Respon yang kami terima dari anakanak cukup baik dibuktikan dengan banyaknya anak-anak yang datang. Kedatangan mereka ada yang hanya sekedar untuk melihat, bermain, dan membaca. Persiapan kami mulai dengan membersihkan tempat, menpersiapakan buku-buku bacaan, dan makanan ringan.

Buku-buku yang tersedia bervariasi mulai dari buku anak-anak sampai remaja. Tentunya anak lebih antusias ketika mereka sudah dihadapkan pada buku kesenangannya. Setiap anak memiliki karaktersitik yang berbeda ada yang keinginan untuk membaca sendiri pandemi yang dibacakan. Di hari pertama melapak kami menemukan anak yang bisa dikatakan belum lancar membaca maka kami pun membimbingnya. Kegiatan ini tidak hanya terfokus pada literasi saja tetapi dari kami mengisi dengan menonton film edukasi, dolanan kawak, keterampilan, disamping mereka membaca untuk menghilangkan rasa bosan.

Pada awal mula berdiri lapak baca dari Bringin Muda Bersemi (BMB) memberikan makanan ringan bagi anak-anak yang berkunjung ke lapak baca. Jadi, tujuan awal kedatangan anak-anak ke lapak baca adalah untuk mendapatkan makanan ringan dan bermain. Namun, lambat laun anak-anak yang berkunjung sudah memiliki ketertarikan bukan hanya untuk mendapatkan makan ringan tetapi untuk mengikuti kegiatan apapun dan sekaligus membaca buku. Kegiatan literasi terus berjalan sampai sekarang dengan tetap mendapatkan donasi buku yang cukup lumayan banyak untuk menambah refensi buku yang ada sehingga terkumpul seluruhnya sekitar 200250 buku.

\section{Metode Penelitian}

Penelitian ini menggunakan pendekatan kualitatif, menghasilkan data deskriptif berupa kata-kata tertulis maupun lisan dari orang-orang dan perilaku yang dapat diamati. Tujuan dari penelitian deskriptif ini adalah untuk membuat deskripsi, gambaran-gambaran atau lukisan secara sistematis, faktual dan akurat mengenai fakta-fakta, sifat-sifat serta hubungan antar fenomena yang diamati. Pengumpulan data melalui observasi, wawancara dan studi dokumentasi. Observasi dilakukan untuk mendapatkan data mengenai eksistensi komunitas Bringin Muda Bersemi (BMB) dalam kegiatan literasi, upaya dalam peningkatan literasi dan implikasi program ahad literasi bagi anak-anak di desa Bringin. Peneliti terjun langsung ke lapangan dengan melakukan pengamatan. Wawancara dalam penelitian ini, mengajukan pertanyaan-pertanyaan yang telah disiapkan sesuai dengan permasalahan yang akan diteliti. Dokumentasi ditunjukan untuk memperoleh data langsung di tempat meliputi buku bacaan, program kegiatan, foto-foto, data yang relevan penelitian. Teknik analisis data yang digunakan adalah deskriptif naratif. Teknis ini menurut Milles dan Huberman diterapkan melalui tiga alur, 
yaitu reduksi data (reduction), penyajian data (data display), dan verifikasi (verification).

\section{Temuan dan Pembahasan}

Eksistensi Komunitas Bringin Muda Bersemi (BMB) dalam Kegiatan Literasi

Eksistensi merupakan salah satu peran dari komunitas Bringin Muda Bersemi (BMB) dalam melakukan kegiatan literasi, peran adalah suatu pekerjaan yang dilakukan dengan dinamis sesuai dengan status atau juga kedudukan tersebut sesuai keteraturan sosial, bahkan dalam tindakan semuanya disesuaikan dengan peran yang berbeda. Sedangkan menurut Sholihah peran adalah serangkaian perilaku yang diharapkan pada seseorang sesuai dengan posisi sosial yang diberikan baik secara formal maupun secara informal. Dari pengertian tersebut dapat disimpulkan peran merupakan suatu tindakan yang dilakukan seseorang yang terbentuk karena adanya masalah sosial untuk melakukan sebuah tindakan yang diinginkan. Tindakan yang dilakukan berkaitan dengan masalah yang terjadi pada komunitas Bringin Muda Bersemi. $^{7}$

Eksistensi dilakukan dengan tujuan agar komunikasi Bringin Muda Bersemi (BMB) dapat terus aktif dan diakui keberadaannya di tengah masyarakat. Menurut Kamus Besar Bahasa Indonesia eksistensi yaitu keberadaan. Menurut Syafirah dan Prasanti, eksisitensi di artikan sebagai keberadaan. Keberadaan yang dimaksud adalah adaya pengaruh atas ada atau tidaknya kita. Eksisitensi perlu diberikan oleh orang lain kepada kita, karena dengan adanya respon dari orang di sekeliling membuktikan bahwa kita diakui keberadaannya. Eksistensi penting, karena merupakan pembuktian akan hasil kerja di dalam suatu lingkungan. Dalam konteks komunitas ini perlu melakukan eksistensi untuk mempertahankan keberadaannya supaya tetap dikenal oleh masyarakat. ${ }^{8}$

Menurut Abdul Syani komunitas terbagi menjadi dua yaitu community dapat dilihat dari dua sudut pandang, pertama memandang community sebagai unsur statis dan sebagai komunitas yang dinamis. Sebagai komunitas yang statis, community dilihat sebagai suatu wadah atau tempat dengan batasbatas tertentu, sehingga dapat menunjukan suatu kesatuan diantara anggota masyarakat sehingga dapat dikatakan sebagai suatu komunitas. Sedangkan komunitas dinamis dilihat bagaimana suatu komunitas melakukan proses

7 Alia Wahyu Adhimi, Yanuar Yoga Prasetyawan, "Peran Komunitas Ruang Literasi Juwana Dalam Upaya Pemberdayaan Masyarakat Di Desa Langgen Kecamatan Juwana," Jurnal Ilmu Perpustakaan, 3 (Agustus 2019), 220.

${ }^{8}$ Ibid., 220. 
sosial yang terbentuk melalui hubungan psikologis dan hubungan antar manusia, maka di dalamnya ada bagian-bagian yang memiliki fungsi dan peranan masing-masing atau pembagian fungsi struktural. ${ }^{9}$

Komunitas Bringin Muda Bersemi (BMB) mulai dikenal oleh masyarakat sejak pertama kali melapak buku di Pelataran TK Darmawanita Bringin. Dalam lapak buku tersebut mengadakan kegiatan literasi yang diikuti oleh anak-anak sampai usia remaja. Selain itu mengikuti pameran buku ketika acara anak-anak KPM. Dimana anak-anak KPM berkolaborasi dengan komunitas Bringin Muda Bersemi (BMB) untuk mengadakan gerakan literasi setiap ahad sore. Promosi dari komunitas Bringin Muda Bersemi yang lain dilakukan melalui sosial media seperti instagram, WhatsAap guna memberi informasi mengenai kegiatan yang akan diselenggarakan.

Selain berperan dalam melakukan eksisitensi, komunitas Bringin Muda Bersemi (BMB) juga memiliki peran untuk menyediakan wadah atau tempat bagi anak-anak untuk menuangkan kreatifitas yang dimiliki melalui kegiatan literasi. Wadah yang disediakan sebagai upaya untuk meningkatkan budaya baca dan kreatifitas dalam menulis. Kegiatan tersebut sebagai bentuk interaksi antara komunitas dan anak-anak serta orangtua. Adanya interaksi tersebut membuat masyarakat lebih mengenal komunitas Bringin Muda Bersemi (BMB).

Kegiatan literasi yang diadakan oleh komunitas Bringin merupakan salah satu upaya untuk mewujudkan tujuan yang ingin dicapai. Untuk itu komunitas Bringin Muda Bersemi (BMB) mengadakan beberapa kegiatan yaitu lapak baca, sinau bareng, nonton film bareng, bimbingan membaca, bimbingan belajar. Kegiatan komunitas Bringin Muda Bersemi (BMB) yang pertama yaitu kegiatan lapak buku. Lapak buku merupakan kegiatan yang dilakukan dengan cara menggelar tikar dan menyusun buku yang ditata dengan memisahkan anatara buku anak-anak dengan buku untuk usia remaja. Buku yang digunakan untuk lapak meliputi Kisah Nabi-Nabi, do'a-do'a, novel, komik, dogeng dan sebagainya. Buku tersebut berasal dari individu dan hasil donasi yang kemudian dikumpulkan menjadi satu.

Peran komunitas dalam kegiatan literasi yaitu memberikan fasilitas dengan menyediakan berbagai buku dan tempat yang nyaman yang digunakan untuk kegiatan membaca dan menulis bagi anak-anak yang berkunjung ke lapak buku. Dari kegiatan literasi menjadi salah satu kegiatan kegiatan rutinann setiap ahad sore. Komunitas Bringin Muda Bersemi (BMB) mengajak anak-anak untuk membiasakan membaca. Kegiatan literasi ini diikuti mulai dari anak-anak sampai remaja, walaupun kebanyakan yang datang anak-anak masih ada sebagaian anak remaja datang sekedar untuk melihat-lihat. Kegiatan literasi ini memiliki tujuan yaitu untuk menumbuhkan

${ }^{9}$ Suardi, Sosiologi Komunitas Menyimpang (Yogyakarta: Writing Revolution, 2018), 2. 
minat membaca yang saai ini rendah karena mudahnya anak mencari atau membaca informasi melalui gadget. Dengan membaca buku akan memberikan wawasan dan pengetahuan dengan memahami informasi yang ada di dalam buku.

\section{Upaya Komunitas Bringin Muda Bersemi (BMB) dalam Meningkatkan Literasi Melalui Ahad Literasi}

Menurut Murti Bunanta upaya yang dapat dilakukan untuk meningkatkan literasi sebagai berikut: ${ }^{10}$

1. Mengadakan kegiatan yang tidak ada kaitan dengan membaca, tetapi karena dilaksanakan di lapak baca maka diharapkan anak-anak akan tertarik untuk membaca buku.

a. Mengadakan kelas melukis, pameran lukisan, dan lomba melukis.

b. Mengadakan keterampilan tangan

c. Mengadakan permainan seperti: kuis, congklak dan lain-lain

d. Pemutaran film untuk anak-anak maupun remaja

2. Mengadakan kegiatan yang berhubungan langsung dengan buku

a. Kegiatan mendongeng dengan menggunakan alat peraga atau meminta langsung kepada anak-anak untuk menjadi tokoh. Bisa juga langsung membacakan dongeng tanpa menggunakan alat peraga.

b. Kegiatan berdiskusi mengenai buku bacaan dengan berbagai jenis tema untuk memperluas wawasan anak.

c. Mengadakan kegiatan penelitian sebagai bentuk untuk meningkatkan rasa ingin tahu terhadap sesuatu dan bentuk menyalurkan kreativitas yang dimiliki anak.

d. Mengadakan pameran buku dengan berbagai jenis tema. ${ }^{11}$

Beberapa upaya diatas yang dijelaskan oleh Murti Bunanta, senada dengan hasil penelitian yang dilakukan peneliti terhadap upaya komunitas dalam meningkatkan literasi. Komunitas Bringin Muda Bersemi diawal kegiatan sebelum terlaksananya kegiatan literasi mengadakan acara yang tidak berhubungan dengan membaca yaitu lomba melukis. Pelaksanaan lomba ini dilakukan di rumah masing-masing yang diikuti oleh anak-anak khusus warga Bringin. Mengenai tema melukis komunitas tidak menentukan tetapi anak-anak mampu berkreasi sendiri. Kegiatan literasi yang diadakan oleh komunitas Bringin merupakan salah satu upaya untuk mewujudkan tujuan yang ingin dicapai. Untuk itu komunitas Bringin Muda Bersemi (BMB) mengadakan beberapa kegiatan yaitu lapak baca, sinau bareng, nonton film bareng, bimbingan membaca, bimbingan belajar. Kegiatan komunitas Bringin Muda Bersemi (BMB) yang pertama yaitu kegiatan lapak buku. Lapak buku

${ }^{10}$ Wahyuni Endah Maulidia, "Studi Kasus Minat Baca Anak di Taman Baca Kampung Pemulung Kalisari Damen Surabaya" (Skripsi, Universitas Islam Negeri Sunan Ampel, 2018), 167.

${ }^{11}$ Ibid., 168. 
merupakan kegiatan yang dilakukan dengan cara menggelar tikar dan menyusun buku yang ditata dengan memisahkan antara buku anak-anak dengan buku untuk usia remaja.

Pelaksanaan kegiatan literasi biasanya dimulai pukul 15.30-17.00. Persiapan pertama, komunitas Bringin Muda Bersemi (BMB) mempersiapkan buku bacaan yang akan di lapak dan menatanya sesuai dengan tingkatannya. Kemudian anak-anak dipersilahkan untuk membaca buku sesuai yang diminati. Setelah membaca selesai dari komunitas Bringin Muda Bersemi meminta kepada anak-anak untuk menulis hasil dari yang dibaca.misalnya membuat ringkasan atau kesimpulan, membuat puisi.

Ketiga, menambah koleksi buku bacaan terutama untuk anak sekolah dasar. Komunitas selalu membuka donasi sejak awal pelaksanaa hingga sekarang. Donasi tersebut tidak berupa uang saja, tetapi juga menerima donasi buku yang layak dibaca. Keempat, memberikan apreasi kepada anakanak. Apresiasi ini diberikan ketika ada acara besar. Kelima, bekerjasama dengan perangkat desa setempat untuk menggunakan fasilitas-fasilitas umum yang dimiliki desa, seperti media yang digunakan untuk menonton film, menggunakan halaman sebagai tempat bermain dan pendopo balai desa sebagai tempat untuk membuka lapak baca. Keenam, mengadakan kegiatankegiatan yang menarik disetiap kegiatan. Menarik perhatian anak-anak agar rutin berkunjung ke lapak baca. Komunitas Bringin Muda Bersemi mengadakan kegiatan bukan hanya membaca buku, anak-anak juga akan mendapat selingan kegiatan seperti edukasi permainan tradisional, perlombaan, membuat karya dan sebagainya.

Upaya terakhir yaitu mengadakan sinau bareng, maksud sinau bareng disini adalah kegiatan belajar dengan memberikan ilmu yang disampaikan oleh kakak-kakak yang sudah berkompeten dalam bidangnya. Dimana sinau bareng ini mayoritas diikuti dari kalangan remaja maupun masyarakat umum. Bentuk sinau bareng ini dilaksanakan melaui sosial media yaitu live instgram. Untuk pelaksanaan diadakan sebulan sekali dengan berbeda pemateri yang mengisi. Tujuan sinau bareng ini berbagi ilmu, informasi kepada masyarakat umum.

\section{Faktor Pendukung dan Penghambat dalam Meningkatkan Literasi Anak di Desa Bringin Kauman Ponorogo}

Meningkatkan literasi pada anak bukanlah sesuatu yang mudah dilakukan, apa lagi jika tidak ditumbuhkan mulai sejak dini. Tentunya dalam pelaksanaan terdapat faktor pendukung dan penghambat yang dapat mempengaruhi. Faktor pendukung adalah faktor yang sifatnya mendukung, menunjang, membantu terhadap suatu kegiatan sedangkan faktor penghambat adalah faktor yang sifatnya menghambat terlaksananya kegiatan.

Terdapat dua faktor pendukung dalam meningkatkan budaya membaca yaitu faktor internal (dari dalam) dan faktor eksternal (dari luar). Faktor 
internal meliputi dukungan dan dorongan dari orangtua. Sedangkan faktor eksternal berasal dari luar seperti lingkungan masyarakat.Faktor pertama dorongan dan dukungan dari orangtua, faktor lain seperti tersedianya buku yang memadai. Buku yang memadai menjadi salah satu faktor pendukung untuk menarik minat anak untuk membaca tanpa adanya buku menjadi penghambat dalam kegiatan literasi. Keinginan anak untuk membaca tentunya dibarengi dengan buku yang menarik, sebagaimana koleksi buku yang ada cukup menarik perhatian anak untuk membaca. Adapun faktor yang terakhir yaitu tempat yang strategis, nyaman, dan mendukung yang akan mendorong semangat anak untuk membaca. Adapun faktor eksternal yang dapat mempengaruhi dalam meningkatkan literasi adalah pertama, adanya dorongan dari lingkungan. Pengaruh lingkungan luar juga menjadi pendorong anak untuk berperan aktif dalam kegiatan literasi.

Disamping faktor pendukung terdapat faktor penghambat dalam proses peningkatan minat baca anak diantaranya yaitu rendahnya budaya membaca yang terjadi pada kebanyakan anak adalah kurangnya rasa kesadaran orangtua tentang pentingnya membaca. Faktor yang terakhir kurangnya tenaga relawan yang berpartisipasi dalam kegiatan literasi. Sehingga, relawan yang ada harus ekstra untuk mengkodisikan anak-anak. Melihat setiap anak mempunyai karakteristik berbeda-beda, ada yang mudah diatur ada pula yang sulit diatur. Partisipasi para relawan sangat dibutuhkan agar kegiatan literasi berjalan sesuai dengan tujuan.

\section{Implikasi Program Ahad Literasi Bagi Anak di Desa Bringin}

Membentuk kebiasaan membaca tidak mudah untuk diwujudkan pada zaman sekarang ini, mengingat kecanggihan teknologi yang yang semakin pesat membuat ketertarikan anak-anak lebih kepada media daripada buku. Waktu mereka juga lebih banyak dihabiskan di depan handpone dibandingankan dengan membaca buku. Untuk itu diperlukan gerakan bersama dari seluruh masyarakat termasuk komunitas untuk mengalakan kegiatan literasi guna meningkatkan baca anak. ${ }^{12}$ Budaya literasi dalam meningkatkan baca dan tulis anak merupakan suatu budaya yang mempunyai tujuan awal dalam mencerdaskan wawasan pengetahuan anak. Dihasilkan generasi bangsa yang kaya akan ilmu pengetahuan. ${ }^{13}$

Program ahad literasi memberikan dampak positif terhadap minat baca anak-anak di desa Bringin. Dampak tersebut dapat dibuktikan dengan banyaknya anak yang antusias untuk mengikuti kegiatan literasi sebelum kegiatan dimulai, mendapatkan pengalaman baru yang sebelumnya belum didapatkan di luar lingkungan sekolah, kebiasaan anak yang awalnya datang

${ }^{12}$ Muslimin, "Penumbuhan Budaya Literasi Melalui Peningkatan Minat Baca Masyarakat Desa”, Jurnal Cakrawala Pendidikan, 1 (Februari 2018), 108.

13 Shiva Ardenia Jatnika, "Budaya Literasi untuk Menumbuhkan Minat Membaca dan Menulis", Jurnal Of Primary Education, 2 (2019), 3. 
untuk bermain tetapi sekarang digunakan untuk membaca walaupun tidak semua anak, sebagian anak menginginkan buku baru karena buku lama telah dibaca semua. Tujuan literasi ini bukan hanya meningkatkan minat baca anak tetapi hasil dari yang dibaca diperoleh pengetahuan dan wawasan yang luas. Berdasarkan hasil wawancara di lapangan menunjukan bahwa anak-anak merasa bosan dengan buku-buku yang tersedia. Kebanyakan anak menginginkan buku baru sehingga hal tersebut membuktikan bahwa minat membaca anak tinggi. Semangat anak akan bertambah jika ada penambahan buku.

Program ahad literasi ini menjadi program rutinan. Sebagaimana yang disampaikan oleh saudara Handoko Endro Saputro bahwa kegiatan literasi ini mampu membawa perubahan bagi anak desa Bringin terkait budaya membaca yang cukup rendah. Adanya kegiatan literasi yang diadakan oleh komunitas Bringin Muda Bersemi (BMB) dapat memberikan sedikit perubahan terhadap peningkatan minat baca anak.

Dengan demikian dapat diketahui bahwa dengan diadakan ahad literasi bagi anak-anak mendapatkan respon baik. Peningkatan minat baca dapat dibentuk melalui program literasi walaupun tidak semua anak mengalami perubahan secara dratis tetapi dapat mengubah kebiasaan anak yang awalnya tidak suka membaca menjadi suka.

\section{Kesimpulan}

Berdasarkan temuan data dan hasil pembahasan yang dipaparkan pada bab sebelumnya, maka peneliti dapat menarik kesimpulan sebagai berikut:

1. Eksistensi komunitas Bringin Muda Bersemi (BMB) dalam kegiatan literasi yaitu memberikan fasilitas dengan menyediakan berbagai buku dan tempat yang nyaman yang digunakan untuk kegiatan membaca dan menulis bagi anak-anak yang berkunjung ke lapak buku.

2. Upaya yang dilakukan oleh Bringin Muda Bersemi (BMB) dalam meningkatkan literasi di desa Bringin sangat beragam, yaitu menyediakan buku bacaan, mengadakan kegiatan yang menarik di setiap edisinya, bekerjasama dengan komunitas yang terkait, mengadakan bimbingan belajar dan membaca, sinau bareng.

3. Faktor pendukung dalam meningkatkan literasi berasal dari lingkungan keluarga yaitu dorongan dan dukungan dari orangtua dan tersedianya buku yang memadai. Dari lingkungan luar seperti ajakan dari temanteman, adanya kerjasama dengan komunitas lain. Adapun faktor penghambat dalam meningkatkan literasi meliputi rendahnya budaya membaca anak, kurangnya kesadaran orangtua terhadap budaya membaca, bermain lebih di senangi daripada kegiatan membaca dan kurangnya partisipasi relawan.

Implikasi program ahad literasi bagi anak-anak di desa bringin dapat memberikan dampak positif. Dibuktikan kebiasaan anak yang awalnya datang 
untuk bermain tetapi sekarang digunakan untuk membaca walaupun tidak semua anak.

\section{Daftar Pustaka}

Charirunnisa. "Pengaruh Literasi Membaca Dengan pemahaman Bacaan (Penelitian Survei pada Mahasiswa STKIP Kusumanegara Jakarta)". Jurnal Tuturan, 1 (Januari 2017).

Departemen Agama RI. Al Qur'an Tajwid E Terjemah. Bandung: CV Penerbit Diponegoro, 2014.

Endah Maulidia Wahyuni. Skripsi: "Studi Kasus Minat Baca Anak di Taman Baca Kampung Pemulung Kalisari Damen Surabaya". Surabaya: Universitas Islam Negeri Sunan Ampel, 2018.

Ibadullah, Dewi Tryanasari, Apri Kartikasari. Pembelajaran Literasi Berbasis Sastra Lokal. Magetan: CV AE Media Grafika, 2017.

Jatnika Shiva Ardenia. "Budaya Literasi untuk Menumbuhkan Minat Membaca dan Menulis". Jurnal Of Primary Education, 2 (2019).

Muslimin. "Penumbuhan Budaya Literasi Melalui Peningkatan Minat Baca Masyarakat Desa”. Jurnal Cakrawala Pendidikan, 1 (Februari 2018).

Rahim Farida. Pengajaran Membaca di Sekolah Dasar. Jakarta: Bumi Aksara, 2008.

Suardi. Sosiologi Komunitas Menyimpang. Yogyakarta: Writing Revolution, 2018.

Wahyu Adhimi Alia, Yanuar Yoga Prasetyawan. "Peran Komunitas Ruang Literasi Juwana Dalam Upaya Pemberdayaan Masyarakat Di Desa Langgen Kecamatan Juwana." Jurnal Ilmu Perpustakaan, 3 (Agustus 2019). 
Wiedarti Pangesti. Desain Induk Gerakan Literasi Sekolah. Jakarta: Direktorat Jenderal Pendidikan Dasar Dan Menengah Kementerian Pendidikan dan Kebudayaan, 2016.

Yayasan Penyelenggara Penerjemah Al-Qur'an, Mushaf Al-Qur'an Terjemah (Jakarta: Al-Huda Kelompok Gema Insani), Juz: 30, Surat: Al-Alaq, Ayat: 1. 
SOUTHEAST ASIAN JOURNAL OF ISLAMIC EDUCATION MANAGEMENT 2 (2) 2021 